\title{
Distribution of Traumatic Spinal Injuries in Turkey In Accordance with ICD-10 Codes between the Years 2015 and 2019
}

\author{
Türkiye'de 2015-2019 Yıllarına ait Travmatik Spinal Yaralanmaların ICD-10 Kodlarına Göre Dağılımı \\ Ümit Ali Malçok, Ali Akar \\ Çanakkale Onsekiz Mart University, Medical School Department of Neurosurgery, Çanakkale, Turkey
}

\begin{abstract}
Introduction: The incidence of traumatic spinal injuries (TSIs) is increasing around the world, our country included. In this study, the distribution of ICD-10 codes used after TSI examinations in Turkey and specifically in Çanakkale between the years 2015 and 2019, and their changes throughout the years were analyzed.

Methods: Nationwide data of Turkey and data of Çanakkale province were obtained from relevant institutions and open access statistics reports. Anatomical regions, types of injury and annual changes in ICD-10 codes of TSI examinations were analyzed.

Results: Across Turkey, the number of medical examinations increased by $18 \%$ in secondary and tertiary care facilities between the years 2015 and 2019. For TSI examinations, the increase was $61 \%$. In Çanakkale province, the number of medical examinations increased by $13.4 \%$ and TSI examinations by $9 \%$ in this 5 -year period. Across Turkey, S33 (919.868) was the most used code in TSI examinations in these 5 years. The least used code was S24 (3.951). In Çanakkale province, it was determined that the code S22 (6508) was used the most, and S24 (23) was used the least. Conclusion: It was determined that TSI examinations across Turkey increased by $61 \%$ in this 5 -year period, and the lumbar region was the most effected. The neural injury rate was high in the cervical region, despite TSI being relatively less common. There was a significant difference between Çanakkale province and Turkey when the ICD code ratios in spinal region were compared. We can conclude from this difference that clinicians use different ICD-10 codes for the same disease. In conclusion, we believe that it should be confirmed that ICD-10 codes actually match the patient's diagnosis in epidemiological studies to be conducted.
\end{abstract}

Key words: Traumatic spinal cord injury, ICD-10, diagnosis code.

\section{INTRODUCTION}

Traumatic spinal injury (TSI) is a serious health problem that affects individuals, society, the healthcare system, and the economy (1). In epidemiological studies across

\section{ÖZET}

Giriş: Travmatik Spinal Yaralanma'ların (TSY) insidansı dünya genelinde olduğu gibi ülkemizde de artmaktadır. Bu çalışmada, Türkiye geneli ve Çanakkale ilinde 2015-2019 yılları arasında, TSY sonrası yapılan muayenelerde kullanılan ICD-10 kodlarının dağılımı ve yıllara göre değişimi analiz edildi.

Yöntemler: Türkiye geneline ve Çanakkale iline ait veriler, ilgili kurumlardan ve açık erişimli istatistik raporlardan temin edildi. TSY muayenesi sonrası kullanılan ICD-10 kodlarının anatomik bölgeler, yaralanma tipleri ve yıllık değişimlerinin analizi yapıldı.

Bulgular: Türkiye genelinde, 2015-2019 yılları arasında ikinci ve üçüncü basamak sağlık hizmeti veren kuruluşlarında yapılan genel muayeneler \%18 oranında artmıştır. TSY muayenelerinde ise bu artış \%61 oranında gerçekleşmiştir. Çanakkale ilindeki genel muayenelerin 5 yılda $\% 13,4$, TSY muayenelerinin ise $\% 9$ oranında artmış olduğu izlendi. Türkiye genelinde 5 yılda yapılan TSY muayenelerinde en çok S33 (919.868) en az ise S24 (3.951) kodu kullanılmıştır. Çanakkale ilinde ise en fazla S22 (6508) kodlu muayenenin yapıldığı, buna karşın en az kullanılan kodun ise S24 (23) olduğu belirlendi.

Sonuç: Türkiye genelinde, TSY muayene sayısının 5 yılda \%61 oranında arttığı ve en çok lomber bölgenin etkilendiği görüldü. TSY'nin nispeten daha az görüldüğü servikal bölgede, nöral yaralanma oranının daha yüksek olduğu izlendi. Toplam TSY sayıları ile karşılaştırıldığında, spinal bölgelere ait kodların kullanım oranlarında, Türkiye geneli ve Çanakkale ilinde belirgin bir fark olduğu görüldü. Bu fark klinisyenlerin aynı hastalıklar için farklı ICD-10 kodlarını tercih etmesine bağlı olduğunu düşündürmektedir. Sonuç olarak, ICD-10 kodlarına göre yapılacak epidemiyolojik çalışmalarda, kullanılmış olan kodların hastaya ait tanı ile uyuşup uyuşmadığının doğrulanması gerektiğini düşünüyoruz.

Anahtar Kelimeler: Travmatik spinal kord yaralanması, ICD-10, tanı kodu.

the world, it was reported that while the incidence of TSI was 10.4 - 83 per million in 2006 (2), it rose to 105 per million in 2018 (3). In Turkey, the incidence was 21 per million in 1992, 16.9 per million in 1997, and 12.7 
per million in 2000 (4-6). Similar to the rest of the world, the incidence of TSIs can be analyzed in accordance with the patient codes defined in the patient records system in Turkey. This coding system was defined as the International Classification of Diseases (ICD-10) (7). ICD-10 started to be used in the world in 1994. In Turkey, it has been used since 2005. In the literature, it was seen that there were not any studies on the distribution of TSI in Turkey in accordance with anatomical regions, the severity of the injury and neurological damage. The aim of this study is to present the distribution of TSI patients across Turkey and in Çanakkale province in accordance with ICD-10 codes and their changes between the years 2015 and 2019. In addition, we aimed to present a preliminary report on whether different ICD-10 selection was made for the same disease and to demonstrate that the results of epidemiological studies could be negatively affected when different codes were chosen.

\section{METHODS}

Our study was approved by Çanakkale Onsekiz Mart University Faculty of Medicine Clinical Research Ethics Committee with decision no 2021-03 dated 03.03.2021. Number of general examinations and ICD-10 codes of TSI examinations from secondary and tertiary care facilities across Turkey and Çanakkale province were used in this study (Table 1). The data was obtained from the Ministry of Health, General Directorate of Health Information Systems, Department of Data Management; with an official letter dated 28.12.2020 and numbered 957413342-042-F-3000. The data of Çanakkale province was obtained from Çanakkale Mehmet Akif Ersoy State Hospital with an official letter dated 27.01.2021 and numbered 133547081. Our study includes the data from the years 2015, 2016, 2017, 2018 and 2019. The number of clinics across Turkey and in Çanakkale was obtained from the Health Statistics Yearbook on the official website of the
Ministry of Health (8). The ICD-10 codes used in TSI examinations were analyzed in accordance with anatomical regions, types of injury and annual changes.

Table 1. Level and related ICD-10 codes of TSI.

\begin{tabular}{|c|c|c|}
\hline $\begin{array}{l}\text { Damaged } \\
\text { region }\end{array}$ & $\begin{array}{l}\text { ICD-10* } \\
\text { code }\end{array}$ & $\begin{array}{l}\text { Affected regions and } \\
\text { anotomical structures }\end{array}$ \\
\hline \multirow{3}{*}{$\begin{array}{l}\text { Cervical } \\
\text { region }\end{array}$} & $\mathrm{S} 12$ & $\begin{array}{l}\text { Fracture of cervical vertebra } \\
\text { and other parts of neck }\end{array}$ \\
\hline & $\mathrm{S} 13$ & $\begin{array}{l}\text { Dislocation and sprain of joints } \\
\text { and ligaments at neck level }\end{array}$ \\
\hline & S14 & $\begin{array}{l}\text { Injury of nerves and spinal cord } \\
\text { at neck level }\end{array}$ \\
\hline \multirow{3}{*}{$\begin{array}{l}\text { Thoracic } \\
\text { region }\end{array}$} & S22 & $\begin{array}{l}\text { Fracture of rib(s), sternum and } \\
\text { thoracic spine }\end{array}$ \\
\hline & S23 & $\begin{array}{l}\text { Dislocation and sprain of joints } \\
\text { and ligaments of thorax }\end{array}$ \\
\hline & S24 & $\begin{array}{l}\text { Injury of nerves and spinal cord } \\
\text { at thorax level }\end{array}$ \\
\hline \multirow{3}{*}{$\begin{array}{l}\text { Lumbar } \\
\text { region }\end{array}$} & S32 & $\begin{array}{l}\text { Fracture of lumbar spine and } \\
\text { pelvis }\end{array}$ \\
\hline & S33 & $\begin{array}{l}\text { Dislocation and sprain of joints } \\
\text { and ligaments of lumbar spine } \\
\text { and pelvis }\end{array}$ \\
\hline & S34 & $\begin{array}{l}\text { Injury of of lumbar and sacral } \\
\text { spinal cord and nerves at } \\
\text { abdomen, lower back and } \\
\text { pelvis level }\end{array}$ \\
\hline
\end{tabular}

${ }^{*}$ Codes definitions are taken from the Rebuplic of Turkey Ministry of Health ICD-10 code system (7). (ICD-10-International Classification of Diseases, TSI-Truamatic Spinal Injury)

\section{Statistical Analysis}

The data was analyzed using SPSS for Windows, version 23.0 (SPSS Inc., Chicago, IL, ABD). Percentages, ratios and mean values were used for descriptive statistics.

\section{RESULTS}

The results were obtained from the analysis of the examinations from secondary and tertiary care institutions. It was seen that the average number of overall examinations in Turkey between the years 2015 
Table 2. The number of second and tertiary general outpatient clinics and examination performed with TSI ICD-10 diagnostic codes in Turkey and Çanakkale.

\begin{tabular}{|c|c|c|c|c|c|c|}
\hline & \multicolumn{3}{|c|}{ General examination } & \multicolumn{3}{|c|}{ TSI examination } \\
\hline & Turkey & Çanakkale & $\% *$ & Turkey & Çanakkale & $\% *$ \\
\hline 2015 & 445.535 .291 & 3.151 .628 & 0,71 & 391.526 & 2.677 & 0.68 \\
\hline 2016 & 469.718 .440 & 3.335 .557 & 0,71 & 438.907 & 3.444 & 0.78 \\
\hline 2017 & 483.789 .191 & 3.249 .443 & 0,67 & 587.833 & 3.605 & 0.61 \\
\hline 2018 & 517.018 .985 & 3.428 .504 & 0,66 & 630.307 & 3.364 & 0.53 \\
\hline 2019 & 524.801 .756 & 3.638 .103 & 0,69 & 628.728 & 2.948 & 0.47 \\
\hline Total & 2.440 .863 .663 & 16.803 .235 & 0,69 & 2.677 .301 & 16.038 & 0.60 \\
\hline$\%^{\alpha}$ & $\% 15$ & $\% 13$ & & $\% 38$ & $\% 9$ & \\
\hline
\end{tabular}

${ }^{*}$ It shows what percentage of the cases in Turkey are in Çanakkale. ${ }^{\alpha}$ The five-year case increase is given as a percentage.

and 2019 was $488 \pm 33$ million. The number of examinations increased from 445.535 .291 in 2015 , to 524.801 .756 in 2019. When compared with 2015, the increase in 2019 was $18 \%$. In Çanakkale province, the number of examinations was 3.151 .628 in 2015 , which reached 3.638.103 in 2019 (Table 2). When compared with 2015, the increase in 2019 was $13.4 \%$. Across Turkey, the number of ICD-10 codes for TSI was 391.526 in 2015 . The number increased by $61 \%$ and reached 628.728 in 2019. In Çanakkale, the number was 2.677 in 2015, and it reached 2.948 in 2019 with an increase of $9 \%$. The average number of examinations was $3.208 \pm 383$ (Table 2 ).

Across Turkey, the total numbers of cervical region injuries in the 5-year period for the codes $\mathrm{S} 12, \mathrm{~S} 13$ and S14 were $85.990,123.957$ and 44.616 respectively. When compared with 2015 , a $67 \%$ increase was seen in cervical region examinations in 2019. Among the three codes, S12 increased the most with $178 \%$, followed by $75 \%$ in $\mathrm{S} 14$ and $22 \%$ in S13. The total numbers of thoracic region injuries in the 5 -year period for the codes S22, S23 and S24 were 583.925, 134.875 and 3.951 respectively. When compared with 2015, an $89 \%$ increase was seen in thoracic region examinations in 2019. Among the three codes, the least amount of increase was 36\% in S23. S22 increased the most with $105 \%$, followed by a $102 \%$ increase in S24. The total numbers of lumbar region injuries in the 5-year period for the codes S32, S33 and S34 were 770.614, 919.868 and 9.505 respectively. When compared with 2015, a $49 \%$ increase was seen in lumbar region examinations in 2019. Among the three codes, the least amount of increase was 10\% in S33. S32 and S34 increased by $121 \%$, and $93 \%$ respectively (Table 3 ).

2.677.301 TSI examination across Turkey and 16.038 in Çanakkale province were performed in the 5-year period between 2015 and 2019. TSIs in Çanakkale constitute $0.6 \%$ of all TSIs in Turkey. A decrease was observed in Çanakkale province in the ICD-10 codes that define all TSIs except S14, S23 and S32.

In contrast, a disproportional increase was seen in the code S23 with 518\%. In TSI examinations in Turkey 
Table 3. Number of examinations in 2015-2019 according to ICD-10* codes belonging to TSI.

\begin{tabular}{|c|c|c|c|c|c|c|c|c|c|c|}
\hline & & \multicolumn{3}{|c|}{ Cervical } & \multicolumn{3}{|c|}{ Thoracic } & \multicolumn{3}{|c|}{ Lumbar } \\
\hline & & S12 & S13 & S14 & S22 & S23 & S24 & S32 & S33 & S34 \\
\hline \multirow[t]{2}{*}{2015} & Turkey & 7.827 & 20.796 & 6.376 & 73.077 & 22.477 & 476 & 91.922 & 167.300 & 1.275 \\
\hline & Çanakkale & 138 & 25 & 71 & 1076 & 22 & 4 & 978 & 344 & 19 \\
\hline \multirow[t]{2}{*}{2016} & Turkey & 11.192 & 23.023 & 6.830 & 85.016 & 24.278 & 567 & 110.471 & 175.990 & 1.540 \\
\hline & Çanakkale & 315 & 37 & 83 & 1575 & 145 & 6 & 1073 & 197 & 13 \\
\hline \multirow[t]{2}{*}{2017} & Turkey & 22.260 & 27.937 & 9.429 & 128.484 & 28.304 & 882 & 171.050 & 197.320 & 2.167 \\
\hline & Çanakkale & 382 & 19 & 72 & 1452 & 255 & 6 & 1291 & 114 & 14 \\
\hline \multirow[t]{2}{*}{2018} & Turkey & 22.934 & 26.733 & 10.804 & 147.277 & 29.259 & 1.066 & 194.278 & 195.900 & 2.056 \\
\hline & Çanakkale & 177 & 0 & 72 & 1360 & 228 & 3 & 1419 & 97 & 8 \\
\hline \multirow[t]{2}{*}{2019} & Turkey & 21.777 & 25.468 & 11.177 & 150.071 & 30.557 & 960 & 202.893 & 183.358 & 2.467 \\
\hline & Çanakkale & 118 & 5 & 85 & 1045 & 136 & 4 & 1476 & 70 & 9 \\
\hline \multirow[t]{2}{*}{ Total } & Turkey & 85.990 & 123.957 & 44.616 & 583.925 & 134.875 & 3951 & 770.614 & 919.868 & 9.505 \\
\hline & Çanakkale & 1130 & 86 & 383 & 6508 & 786 & 23 & 6237 & 822 & 63 \\
\hline
\end{tabular}

*ICD-10-International Classification of Diseases, TSI-Traumatic Spinal Injury.

between the years 2015 and 2019, the most common code was S33 with 919.868 , followed by S32 with 770.614. The code S24 was the least used one with 3.951. In Çanakkale province, the most common code for examinations was S22 and S32; and the least used code was S24 (Table 3).

\section{DISCUSSION}

In the 5-year period of 2015 to 2019 , the examinations in secondary and tertiary care facilities increased by $18 \%$ across Turkey. However, the increase was $61 \%$ in TSI examinations. When compared with the number of overall examinations, it was seen that the increase in TSIs was higher. However, the increase was not equal in different TSI codes. For instance, examinations with the code S12 increased by $178 \%$ across Turkey. In Çanakkale province, it was seen that the $13.4 \%$ increase in overall examinations was in line with the $9 \%$ increase in TSI examinations. However, the change in the code S23 was not coherent, and there was a significantly higher increase in the code S23 with 518\%. Across Turkey, it was seen that the code S13, which defines joint and ligament injuries, was the most used code for cervical region injuries. The 5-year total for the cervical vertebra fracture code S12 was 85.000 , and it was 44.000 for the neural injury code S14. This suggests that neural injury was identified in one of every two cervical vertebra fractures. Neural injury ratios of thoracic and lumbar region TSIs varied between $0.3 \%$ and $0.9 \%$ across Turkey and in Çanakkale province. On the other hand, the ratio of neural injury in cervical region TSIs varies between 18$24 \%$. In conclusion, neural injury ratios were much higher in cervical region TSIs in comparison with other spinal regions. There isn't any data on the clinical preference of codes in a cervical fracture case with 
accompanying neural injury. According to a study that analyzed code preferences, the incidence of spinal cord injuries was overcalculated with the numbers from hospital databases. These results were reported to be unreliable in health planning (9). For instance, while selecting the ICD-10 diagnosis, S14 might be selected together with $\mathrm{S} 12$, or only one of these codes might be preferred. This possibility cannot be excluded in epidemiological studies conducted using only the code system. There are studies in the literature stating that whether the codes selected exactly match the disease diagnoses can only be determined by going over the patient records one by one $(9,10)$.

It was seen that the usage ICD-10 codes for the cervical region increased by $67 \%$ across Turkey. However, it decreased by $11 \%$ in Çanakkale province. A similar change was seen in the thoracic region. However, even though the usage of codes for lumbar regions increased by $93 \%$ across Turkey, they decreased by $53 \%$ in Çanakkale. In our study, it was seen that the increase in the number of TSI examinations was higher compared to all examination across Turkey. In contrast, the increase in both types of examinations was proportional in Çanakkale province however the increase in TSIs was not proportional to the increase in ICD-10 codes for cervical region.

This could be explained by the doctors' different attitudes in diagnosing the patients and selecting diagnosis codes. When all TSI codes across Turkey were analyzed, it was seen that the lumbar region was seen the most with $63.5 \%$, followed by the thoracic region with $27 \%$ and the cervical region with $9.5 \%$. Across Turkey, the fracture code $\mathrm{S} 12$ was $34 \%$, and the joint and ligament injury code $\mathrm{S} 13$ was $49 \%$ of all cervical region SCls. In contrast, S12 was $71 \%$ and $\mathrm{S} 13$ was $5 \%$ in Çanakkale province. This mismatch in cervical region injuries could be explained by the doctors selecting different codes for similar diagnoses.
It was determined that the code most used to classify thoracic region injuries across Turkey was the fracture code S22 (80.9\%), followed by S23 (18.7\%) and S24 $(0.5 \%)$. In contrast with the cervical region, only a small number of neural injuries were seen in the thoracic region. In addition, there was a similar amount of increase in the fracture code S22 (105\%) and the neural injury code S24 (102\%). However, it was found that the 5-year increase of Çanakkale province was not coherent with the nationwide data. In Çanakkale province, a $3 \%$ decrease was seen in the code S22 and there was not any change in the code S24. Neural injuries were seen in $0.5 \%$ of all thoracic injuries and in $0.6 \%$ of all lumbar injuries. This result reflects the nationwide data and shows that there is not a significant difference between the thoracic region and lumbar region injuries in TSI in terms of neural injury risk.

It was seen that the overall increase in the TSI codes across Turkey between the years 2015 and 2019 was not coherent with the regional increases in cervical, thoracic and lumbar regions. Even though the usage of fracture (45.3\%) and joint and ligament injury (54.1\%) codes were similar in lumbar region injuries, there was an accumulation on the fracture code $\mathrm{S} 32(87.6 \%)$ in Çanakkale province. In addition, there was not a significant difference between the use of neural injury codes in the lumbar region. For instance, joint and ligament injuries were found to be higher after TSI across Turkey compared to Çanakkale. This difference suggests that the code choices of doctors performing lumbar TSI examinations change according to their attitudes. The 5-year change in the thoracic and lumbar region codes were similar across Turkey, however, this was not the case in Çanakkale province. This difference between the nationwide data and Çanakkale province suggests that the real diagnoses of trauma patients do not always match the ICD-10 codes.

\section{Limitations}


Our study was conducted using nationwide data, and as such, repeat patients and duplicate ICD-10 code entries could not be separated. In order to overcome this limiting situation, we think that programs adapted to the ICD-10 system should be used to determine the number of repeat patients. Even though the selection of codes after the examinations were made by specialists, whether the codes exactly match the disease was not checked by an independent observer. Another limitation of the study is that due to the fact that the majority of TSI patients are treated in secondary and tertiary care facilities, the records from primary care facilities were not included in the study.

\section{CONCLUSION}

This study is the first to present the distribution of ICD10 codes across Turkey. The distribution of TSI patients in accordance with their ICD-10 codes across Turkey and in Çanakkale province was analyzed in this study. It was seen that the most common region for spinal injuries was the lumbar region. Although the cervical region did not get injured as frequently, the rates of neurological injury were much higher. In the lumbar and thoracic regions, the rates of neurological injury were quite low. When the nationwide data was compared with Çanakkale province, it was seen that the distributions of the codes were not similar. This suggests that different clinicians prefer different codes. Using different ICD-10 codes for the same disease will negatively affect the results of epidemiological studies. Therefore, national or international trauma prevention studies using these records will also be negatively affected. We believe that selecting the most accurate code for the TSI disease groups should be encouraged in Turkey and around the world. Awareness should be raised about the importance of ICD-10 code selection.

Conflict of Interest: The authors declare that they have no conflict of interest.

Funding: No funding was taken for this study.

\section{REFERENCES}

1. Ackery A, Tator C, Krassioukov A. A global perspective on spinal cord injury epidemiology. J Neurotrauma. 2004 Oct;21(10):135570.

2. Wyndaele $\mathrm{M}$, Wyndaele J-J. Incidence, prevalence and epidemiology of spinal cord injury: what learns a worldwide literature survey? Spinal Cord. 2006 Sep;44(9):523-9.

3. Kumar R, Lim J, Mekary RA, Rattani A, Dewan MC, Sharif SY, et al. Traumatic Spinal Injury: Global Epidemiology and Worldwide Volume. World Neurosurg. 2018 May;113:e345-63.

4. Karamehmetoğlu SS, Unal S, Karacan I, Yílmaz H, Togay HS, Ertekin $\mathrm{M}$, et al. Traumatic spinal cord injuries in Istanbul, Turkey. An epidemiological study. Paraplegia. 1995 Aug;33(8):469-71.

5. Karamehmetoğlu SS, Nas K, Karacan I, Sarac AJ, Koyuncu H, Ataoğlu $\mathrm{S}$, et al. Traumatic spinal cord injuries in southeast Turkey: an epidemiological study. Spinal Cord. 1997 Aug;35(8):531-3.

6. Karacan I, Koyuncu H, Pekel O, Sümbüloglu G, Kirnap M, Dursun $\mathrm{H}$, et al. Traumatic spinal cord injuries in Turkey: a nation-wide epidemiological study. Spinal Cord. 2000 Nov;38(11):697-701.

7. Türkiye Cumhuriyeti Sağlık Bakanlığı Sağlık Hizmetleri Genel Müdürlüğü Sosyal Güvenlik Uygulamaları Dairesi Başkanlığı. July $\quad 1, \quad 2005 . \quad$ Available at: https://shgmsgudb.saglik.gov.tr/TR,6220/icd-10-trm-hastalik-vesaglik-girisimi-siniflandirma-sistemleri-gelistirilmesi.html Acccessed 24 February 2021.

8. Türkiye Cumhuriyeti Sağlık Bakanlığı İstatistik Yıllıkları. May 29, 2015. Available at: https://www.saglik.gov.tr/TR,11588/istatistikyilliklari.html Acccessed 24 February 2021.

9. Hagen EM, Rekand T, Gilhus NE, Gronning M. Diagnostic coding accuracy for traumatic spinal cord injuries. Spinal Cord. 2009 May;47(5):367-71.

10. Bellner J, Jensen S-M, Lexell J, Romner B. Diagnostic criteria and the use of ICD-10 codes to define and classify minor head injury. J Neurol Neurosurg Psychiatry. 2003 Mar;74(3):351-2. 